\title{
Toxicological Response of Poecilia reticulata, Hyla species and Culex species to Leachates from Olusosun Landfill, Lagos State, Nigeria
}

\author{
*11ADETORO, FA; ${ }^{2}$ IKUABE, BO; ${ }^{3}$ LAWAL, RA \\ ${ }^{1 *}$ Applied Entomology and Pest Management Unit, Department of Zoology, ${ }^{2}$ Environmental Toxicology and Pollution Management Unit, \\ Department of Zoology, ${ }^{3}$ Department of Biochemistry, College of Medicine University of Lagos Akoka, Lagos, Nigeria \\ *Corresponding Author e-mail: fadetoro@unilag.edu.ng;benedicta.ikuabe@yahoo.com; rlawal@unilag.edu.ng
}

\begin{abstract}
The effect of leachate samples from Olushosun dumpsite in Ojota, Lagos on the toxicological response of Poecilia reticulata, Hyla and Culex species was investigated using acute and chronic toxicity tests. Physicochemical parameters were analysed in the leachate prior to toxicological assessment against test animals. Computed results showed that $\mathrm{pH} 7.62$ while the acute toxicity assay of leachate sample against test animals revealed a $96 \mathrm{hr} \mathrm{LC} 50$ of $71.53 \mathrm{ml} / \mathrm{L}, 58.34 \mathrm{ml} / \mathrm{L}$ and $60.643 \mathrm{ml} / \mathrm{L}$ for Poecilia, Hyla and Culex species respectively. On the basis of the $96 \mathrm{hr} \mathrm{LC}_{50}$ values, the leachate was found to be more toxic against Hyla than Poecilia. The exposure of the Poecilia and Hyla species to sub-lethal concentrations $\left(1 / 10^{\text {th }}\right.$ of $\left.96 \mathrm{hrs} \mathrm{LC}_{50}\right)$ of leachate revealed varied biochemical responses over a 28 day period. The activity of Catalase, Superoxide Dismutase (SOD), Malondialdehyde (MDA) and Glutathione-S-Transferase (GST) showed significant increase $(\mathrm{p}<0.05)$ when compared to control in Hyla while the activity of GSH, SOD and CAT showed significant increase $(\mathrm{p}<0.05)$ when compared to control in Poecilia sp. Results from this study showed that leachate can induce adverse environmental effect on organisms. The acute and chronic toxicological response of the test animals could be incorporated into risk assessment of dumpsite leachate, design and management of landfill sites.
\end{abstract}

\section{DOI: https://dx.doi.org/10.4314/jasem.v22i5.38}

Copyright: Copyright (c) 2018 Adetoro et al. This is an open access article distributed under the Creative Commons Attribution License (CCL), which permits unrestricted use, distribution, and reproduction in any medium, provided the original work is properly cited.

Dates: Received: 09 March 2018; Revised: 14 April: 2018; Accepted: 22 April 2018

Keywords: Leachates, Poecilia reticulata, Culex species, Malodialdehyde, Glutathione-S-Transferase

Landfilling is the main municipal solid waste disposal method used worldwide (Dave and Nilsson, 2005). In Nigeria, open dump is almost the verily available option for solid waste disposal even in the capital cities, as relevant institutions are either weak or underfinanced even in the face of rapid population growth (Elaigwu et al., 2007). Landfill leachate is produced when moisture from rain water, groundwater, surface water and snow (in temperate countries) enters the dumping site of landfill (Kulikowska and Klimiuk, 2008). While moisture percolates through the waste, it carries along organic, inorganic, heavy metals, colloid, pathogen and other polluted matters (Zin et al, 2012). Liquids which are not absorbed or evaporated will flow outward and downward, transporting contaminants from within the landfill. Leachate composition varies significantly among landfills depending on waste composition, waste age and landfilling technology (Kjeldsen $e t$ al., 2002). It potentially contributes to environmental pollution which will affect groundwater and surface water (Kjeldsen et al., 2002). The characteristic of leachate produced depends on the materials disposed in the landfill. Other factors that influence toxic contaminants in leachate are the decomposition of solid waste, precipitation rates, waste age, and landfill design and operation (Bhambulkar, 2011). Leachate contains substantial amounts of dissolved organics (BOD and COD), Xenobiotic Organic Compound (XOCs), inorganic salts, ammonia, heavy metals and other toxicants (Christensen et al, 2001; Pivato and Gaspari, 2005).

Chemical analysis only detects a small percentage of the toxic compounds present in leachate samples. Bioassay toxicity tests can measure effects on organisms and can also detect toxicity even when the contaminants are not identified by chemical analysis. Most living organisms depend on ATP generation by oxygen-based metabolism, but one consequence of oxygen dependence is the production of reactive oxygen species (ROS) such as superoxide $\left(\mathrm{O}^{2 \cdot}\right)$, hydrogen peroxide $\left(\mathrm{H}_{2} \mathrm{O}_{2}\right)$, and hydroxyl radical $\left(\mathrm{OH}^{-}\right)$, mainly as by product of oxidative metabolism. The mitochondrial electron transport chain and a variety of cellular oxidases are the main sources of ROS generation (Zhang et. al, 2003). ROS can attach multiple cellular constituents, including proteins, 
nucleic acids, and lipids. To cope with damaging actions of ROS, organisms have evolved multiple systems of antioxidant defence. So called lowmolecular weight antioxidants include metabolites such as glutathione, ascorbic acid, uric acid, etc. whereas high-molecular weight defences include enzymes such as superoxide dismutase (SOD), catalase, glutathione peroxidase (GPx), glutathione reductase (GRx) and glutathione-s-transferase (GST). These enzymatic and non-enzymatic constituents deal directly with radical species and protect against intoxication of any damage to the macro and micro molecules in body

The Ojota area of Lagos, Nigeria has the largest municipal landfill situated at Olushosun, it has received more than $50 \%$ of the total refuse in Lagos area since 1989. It receives domestic, industrial and institutional waste by public and private waste management operators. Hence, in the present study, the effect of leachate on the enzymes superoxide dismutase (SOD), Glutathione-S-Transferase (GST), reduced glutathione (GSH), Malondialdehyde (MDA) and catalase (CAT) activity in Poecilia reticulata and Hyla species were analyzed.

\section{MATERIALS AND METHODS}

Leachate sample collection and storage: Leachate samples were collected in 5 litres plastic containers from the leachate 'swamps'. They were collected in prewashed polyethylene bottles, taken to the laboratory, and kept at $4^{0} \mathrm{C}$ in a refrigerator.

Collection and transportation of test organism: The test organisms used were the Poecilia reticulata, Hyla species and Culex Species which served as the bioassay organisms. Poecilia reticulata and tadpoles of Hyla species were collected from the wild in adjoining canal systems around UNILAG Akoka Campus. They were transported to the Zoological Garden laboratory, University of Lagos in plastic containers containing the habitat water, and partially opened to enable aeration. In the laboratory, the fish and tadpoles were sorted into separate large water holding tank. Culex Species was collected from pools in abandoned tyres at Onike-Iwaya, a suburb of Yaba, Lagos State. They were collected in plastic containers and taken to the laboratory where they were then transferred into plastic containers.

Acclimitization of test animals: The fish were kept in plastic tanks $(35 \mathrm{x} 30 \mathrm{x} 45 \mathrm{~cm})$ which were half filled with dechlorinated water. They were acclimatized to laboratory conditions for one week. During acclimatization, the juveniles were fed with their natural fish feed. The fish were fed daily and the water was changed every other day with dechlorinated water to prevent the accumulation of waste metabolite and food particles. The tadpoles were collected in a plastic container and taken to the laboratory, where they were maintained in holding tanks and acclimated for a week. They were fed with natural fish feed. The water was changed every other day with dechlorinated water to prevent the accumulation of waste metabolite and food particles. The mosquito larva were collected in plastic containers and taken to the laboratory where they were then transferred into plastic containers and acclimatised in water from their natural environment for few hours before the start of the toxicity tests.

Assessment of quantal response (mortality): The test organisms were considered dead if they showed no body or opercula movements even when gently prodded with a glass rod.

Acute toxicity of leachate sample against test organisms: Ten fishes in three replicates were used per tank containing 10, 20,35, 50 and $75 \mathrm{ml} / \mathrm{L}$ of leachate sample. A control with only de-chlorinated tap water ( $0 \%$ dilution) was also included. Mortality was assessed at 24, 48, 72 and 96 hour intervals after the commencement of the test. The fish were taken as dead, if they did not show any signs of movement on examination and gentle prodding. Fish were not fed throughout the duration of the test, which lasted 96 hours, with mortality assessed at time intervals of 24 , 48, 72 and 96 hours after the commencement of the tests. The same procedure was adopted for tadpoles of Hyla species and in the case of Culex larvae, twenty individuals in three replicates were exposed to similar concentrations of leachate samples to determine acute toxicity.

Sub-lethal assays: A similar experiment described above in acute toxicity assay was also carried out except that the test concentrations were based on fractions $\left(1 / 10^{\text {th }}\right.$ and control $)$ of the derived $96 \mathrm{hr} \mathrm{LC}_{50}$ values from the acute toxicity experiment. Poecilia reticulata was exposed to $1 / 10^{\text {th }} \mathrm{LC}_{50}$ obtained from its acute toxicity test and that of Culex species; Hyla species was also exposed to $1 / 10^{\text {th }} \mathrm{LC}_{50}$ obtained from its acute toxicity test and that of Culex species. During these sublethal tests, the setup was renewed every 3 days for 28 days in order to maintain test concentrations over the period and the test organisms were fed daily with their natural feed.

Statistical analysis: Data were analysed using descriptive tests and means separated by analysis of variance (ANOVA) and to confirm the variability of data and validity of results, and Duncan's Multiple 
Range Test was performed to determine the significant differences between treatments using SPSS 20 (IBM). $P<0.05$ was considered statistically significant.

\section{RESULTS AND DISCUSSION}

Physicochemical properties of Olushosun leachate sample: Homonogenized leachate samples were analysed using volumetric analysis. It was observed that $\mathrm{pH}$, conductivity, TDS, nitrates and chloride ion concentrations were higher than regulatory safe limits. In the same vein, leachate concentrations of lead, cadmium, zinc, chromium, and copper were higher than safe limits by global and national standards (Table 1).

Table 1: The physicochemical characteristics of the Olushosun Leachate

\begin{tabular}{llll}
\hline $\begin{array}{l}\text { Physicochemical } \\
\text { parameters }\end{array}$ & $\begin{array}{l}\text { Leachate } \\
\text { sample }\end{array}$ & \multicolumn{2}{l}{ STANDARDS } \\
\cline { 3 - 4 } & & WHO & FEPA \\
& & & \\
pH & 7.62 & $6.5-$ & $6-9$ \\
& & 8.5 & \\
EC $(\mu \mathrm{s} / \mathrm{cm})$ & 5730 & 1000 & $\mathrm{NS}$ \\
TDS $(\mathrm{mg} / \mathrm{l})$ & 3061.64 & 1000 & 2000 \\
Nitrate(mg/l) & 253.84 & 50 & 20 \\
Ammonia(mg/l) & 10.97 & $\mathrm{NS}$ & $\mathrm{NS}$ \\
Chloride(mg/l) & 18817.64 & 250 & 600 \\
Sulphate(mg/l) & 214.47 & 400 & 500 \\
BOD(mg/l) & 455.10 & $\mathrm{NS}$ & $\mathrm{NS}$ \\
COD(mg/l) & 873.83 & $\mathrm{NS}$ & $\mathrm{NS}$ \\
Lead(mg/l) & 12.98 & 0.01 & $<1$ \\
Cadmium(mg/l) & 6.33 & 0.005 & $<1$ \\
Zinc(mg/l) & 8.39 & 3 & $<1$ \\
Chromium(mg/l) & 4.86 & 0.05 & $<1$ \\
Copper(mg/l) & 3.84 & 1 & $<1$ \\
\hline
\end{tabular}

Key: $W H O=$ World Health Organization, FMEnv $=$ Federal Ministry of Environment, EC=Electrical Conductivity, NS= Not specified, $T D S=$ Total Dissolved solids, $B O D=$ Biological Oxygen Demand

The $\mathrm{pH}$ value is an indicator of the aggressiveness of the leachate and aerobic versus anaerobic conditions in the refuse. The measured $\mathrm{pH}$ value was relatively around neutral (7.62) which is within the allowable limits. The alkaline $\mathrm{pH}$ observed in the leachate can be attributed to the methane fermentation phase of the landfill. In this phase, alkaline $\mathrm{pH}$ supports the growth of methanogens which converts much of the organic contaminants in leachate to methane gas (McBean et $a l$, 1995). An environmental consequence of this phase is the landfill fires that occur frequently on the landfill site in the dry season due to spontaneous combustion. The high level of inorganic contamination in the leachate as shown by the high concentrations of TDS and EC observed agrees with the report of Mor et al. (2006). Leachate from municipal landfill usually contain very low Dissolved Oxygen (DO) levels because of waste compression processes and also due to aerobic decomposition of the wastes in which microbes use up oxygen to transform organic materials to inorganic substances (Bagchi, 1994). Several bulk parameters are used to describe the content of dissolved organic matter in leachate, Total Organic Carbon (TOC), Chemical Oxygen Demand (COD) and Biological Oxygen Demand (BOD). This study included the measurements of COD and BOD. These values are generally within the normal range of typical municipal landfill leachate (Kjeldsen et al., 2002). A BOD/COD ratio greater than 0.5 indicates a young landfill, when the ratio is less than 0.1, the landfill can be considered old and stable, whereas the ratio 0.1-0.5 indicates partially stable leachate (Kjeldsen et al., 2002). Therefore, in the given leachate, the value of BOD/COD ratio was 0.5 which indicates the partial stabilization of the leachate. Ammoniacal-nitrogen $\left(\mathrm{NH}_{3}-\mathrm{N}\right)$ is a common constituent of landfill leachate as a result of the biological degradation of amino acids and other nitrogenous organic matter. $\mathrm{NH}_{3}-\mathrm{N}$ seems to be the constituent that lasts long term in landfill leachate and may be used to determine the remaining pollution potential in the landfill and the required after-care period (Kruempelbeck and Ehrig, 1999). Concentration of $\mathrm{NH}_{3}-\mathrm{N}$ in the landfill leachate was 11 $\mathrm{mg} \mathrm{L}^{-1}$. The role of ammonia and alkalinity as potential toxicant in landfill leachates has been hypothesized by several authors (Clement et al, 1996; Clement and Merlin, 1995). Total Dissolved Solids (TDS) in the examined leachate was $3061 \mathrm{mg} \mathrm{L}^{-1}$ was measured. These values in turn may reflect the large content of soluble ions particularly inorganic. Khoury et al. (2000) had noticed a positive correlation between the variation of EC and TDS in the municipal landfill leachate.

The presence of high levels of heavy metals in the leachate suggests their origin could be from the various wastes dumped in the landfill. The presence of high concentration of $\mathrm{Fe}$ in the leachate indicates that Fe scraps are likely to be dumped in the landfill. Elevated levels of $\mathrm{Pb}$ in leachate had also been observed by Moturi et al. (2004) and this may be attributed largely to the disposal of batteries, leadbased paints and lead pipes found at the site. The high value of $\mathrm{Zn}$ may be attributed to the presence of fluorescent tubes, batteries, and a variety of food wastes as well as the burning tyres at the site. The discarding of dry cell batteries and paint cans are the possible sources of cadmium. 
Relative acute toxicity of leachate against Poecilia reticulata, Hyla species and Culex species: On the basis of $96 \mathrm{hrs} \mathrm{LC}_{50}$ values, the leachate was found to be more toxic on Hyla sp (with $\mathrm{LC}_{50}$ value of
$58.33 \mathrm{ml} / \mathrm{L}$ ) compared to the guppy fish (with $\mathrm{LC}_{50}$ value of $71.53 \mathrm{ml} / \mathrm{L}$ ). The $\mathrm{LC}_{50}$ of Culex $s p$ exposure to leachate was $60.64 \mathrm{ml} / \mathrm{L}$ (Table 2).

Table 2: Relative Acute toxicity (m1/L) of leachate against Poecilia reticulata, Hyla species and Culex species

\begin{tabular}{lllllll}
\hline Time (96 hrs) & ${ }^{*} \mathbf{L C}_{\mathbf{5}}$ & ${ }^{*} \mathbf{L C}_{\mathbf{5 0}}$ & ${ }^{*} \mathbf{L C}_{\mathbf{9 5}}$ & SE & DF & Probit Line Equation \\
\hline P. reticulata & 14.546 & 71.529 & 87.926 & 2.80 & 3 & $\mathrm{Y}=-7.81+(-2.79 \mathrm{x})$ \\
Hyla sp & 19.489 & 58.327 & 39.464 & 5.01 & 3 & $\mathrm{Y}=-16.33+(-3.26 \mathrm{x})$ \\
Culex species & 9.134 & 60.643 & 402.625 & 0.83 & 3 & $\mathrm{Y}=-3.57+(-4.28 \mathrm{x})$ \\
\hline
\end{tabular}

*Concentrations are in $\mathrm{ml} / \mathrm{L}$

The low $\mathrm{LC}_{50}$ observed in the toxicity studies indicate that the leachate is toxic; producing dose-responsive increases in mortality. In toxicity testing, the use of representative organisms from different levels of the food chain more faithfully displays the range of response to toxicants than use of test organisms from one particular level (Cairns, 1956). Furthermore, testing with several species from different taxonomic groups gives a better indication of the natural variability in the levels of the toxicants in causing an observed effect (Rand, 1995). Accordingly, this study adopted a multispecies (fish, amphibian and insect) approach, which is more indicative of the effects of particular toxicant(s) on aquatic organisms. The contaminants or constituents in the leachate are believed to have induced the observed effects or mortality. These results suggest that of the test organisms used, the tadpole is most sensitive to the leachate.

Chronic toxicity study sub-lethal study: Reduced Gluthatione (GSH) level in Hyla sp and Poecilia reticulate: Measurement of GSH activities in the liver of Hyla sp exposed to $0.58 \mathrm{ml} / \mathrm{L}$ sublethal concentration of the leachate over a 28 day period showed no significant increase when compared to control except on day 28, GSH activity increased significantly $(\mathrm{P}<0.05)$. In the case of Poecilia sp., GSH activities in the liver showed significant difference $(\mathrm{p}<0.05)$ at days 14 and 28 compared to control (Table 3). Glutathione is an antioxidant quite popular for its ability to minimize oxidative stress (Kerksick and Willoughby, 2005). It largely acts by minimizing the lipid peroxidation of cellular membranes and other such targets that is known to occur with oxidation stress. In this study there was no significant difference in the level of reduced glutathione (GSH) in Hyla sp. not exposed to leachate during the period of exposure. However, there was a significant increase in the level of GSH in Hyla sp. exposed to leachate on day 28 compared to control. Glutathione is endogenously synthesized in most cells of the body (Sen and Packer, 2000) in response to stress.
Superoxide Dismutase (SOD) levels in Hyla sp and Poecilia reticulata: The SOD activity in the liver of Hyla $s p$ exposed to leachate increased significantly $(\mathrm{p}<0.05)$ in $0.58 \mathrm{ml} / \mathrm{L}$ sub-lethal concentration relative to control on days 14 and 28 , while the same trend was only observed in day 14 for Poecilia reticulate following exposure to $0.72 \mathrm{ml} / \mathrm{L}$ sub-lethal leachate relative concentration compared to control (Table 3). Superoxide is the free radical produced during the natural pathway of oxidative phosphorylation. The enzyme superoxide dismutase (SOD) is an intracellular antioxidant enzyme which readily dismutase superoxide (Kerksic and Willoughby, 2005). The superoxide dismutase enzyme converts superoxide primarily into hydrogen peroxide. The exposure of Hyla sp. to $0.58 \mathrm{ml} / \mathrm{L}$ leachate led to significance time dependent increases in the activity of SOD when compared to control at days 14 and 28. In Poecilia, the significant increase in the SOD activity when compared to control was observed only on day 14 . However, the change recorded on day 28 was not significant. The increases recorded in superoxide dismutase activities in the species exposed to leachate may be due to induction of enzyme synthesis by oxidants present in the leachate (Idowu et al, 2014).

Catalase level in Hyla sp and Poecilia reticulate: The results also showed that Catalase enzyme activity increased in Hyla sp exposed to leachate relative to the control, although not significantly $(\mathrm{p}>0.05)$. There was no significant increase in the liver for 14 and 28 days (Table 3). The catalase enzyme activity in the liver of Poecilia reticulate exposed to leachate relative to the control showed significant increase $(\mathrm{p}<0.05)$ in sub-lethal concentration $0.72 \mathrm{ml} / \mathrm{L}$ relative to control. Catalase is a tetrameric $240 \mathrm{KDA}$ enzyme which reacts very efficiently with $\mathrm{H}_{2} \mathrm{O}_{2}{ }^{\mathrm{lg}}$ to form water and molecular oxygen. Catalase is known to protect to protect cells from hydrogen peroxide generated within them (Roos et al, 1980). In Hyla sp., there was a significant increase in the activity of catalase compared to control on days 14 and 28. However, in Poecilia sp. there was a significant increase recorded 
in the activity of catalase when compared to control in day 28 .

Lipid Peroxidation (MDA) level in Hyla sp and Poecilia reticulata: Measurements of MDA in the liver of Hyla sp exposed to leachate increased relative to control showed significant increase $(\mathrm{p}<0.05)$ at day 14 and 28 when compared to control organisms. In the case of Poecilia reticulate, MDA activity was only significantly different $(\mathrm{p}<0.05)$ at day 28 when compared to control organisms (Table 3). Lipid peroxidation is the systematic oxidation by free radicals fatty acids in the cell membranes. This is known to limit cells function by decreasing the fluidity of the membrane. A bye-product of lipid peroxidation, Malondialdehyde (MDA) is used to access the level of lipid peroxidation. In Hyla sp., there was a significant increase in the level of lipid peroxidation on day 28 when compared to control. There was however, no significant change in the level of MDA in Poecilia sp., when compared to control organisms. The increased lipid peroxidation observed in Hyla sp. may be due to the presence of reactive oxygen species (Taniguchi et al., 1999) in the leachate. The elevated level of lipid peroxidation in the liver of $P$. Reticulate and Hyla $s p$ in response to the exposure to leachate as observed in the present investigation suggests that there is increased production of ROS and that certain substances from leachate caused damage to membrane lipids of the liver. The liver is noted as site of multiple oxidative reactions and maximal free radical generation (Avci, 2005). Oxidative injury to $P$. Reticulate and Hyla sp bio-membrane can be attributed to $\mathrm{Zn}$ and $\mathrm{Cr}$ since it was present in larger quantities in landfill leachate samples. Non-redox metals such as $\mathrm{Zn}$ and $\mathrm{Cr}$ increase the production of reactive oxygen species (ROS) indirectly by interfering with the animal's antioxidant defence system (Horvat et al, 2007). Zhu et al. (2007) observed enhanced ROS generation via Mehler reaction and consequent increased lipid peroxidation as a result of ammonia. Antioxidative enzymes, such as catalase, can serve as important markers of stress caused by environmental pollution. In several studies, heavy metals have been found to be potent inducers of catalase (Fatima and Ahmad, 2005).

Glutathione-S-Transferase (GST) level in Poecilia reticulate: There was a significant decrease $(\mathrm{p}<0.05)$ in GST activity in the liver of Hyla sp exposed to $0.58 \mathrm{ml} \backslash \mathrm{L}$ leachate on day 14 compared to control (Table 3).The GST activities in the liver of Poecilia reticulate exposed to sublethal concentration of leachate only showed an increased on day 14, and later dropped at day 28, with no significant difference ( $p>0.05)$ observed (Table 3 ). Glutathione reductase activity is the enzyme responsible for restoring reduced glutathione from oxidized glutathione through the use of nicotinamide adenine trinucleatide (Mannervik, 2001). In this study, in the glutathione reductase activity was thought to suggest an increase of oxidative stress due to exposure to leachate.

In Poecilia sp, no significant change was observed in control and through the days during exposure. There were increases in the level of GSH on days 14 and 28. This shows an early onset of the increase compared to control in the GSH level may be due to the high concentration of the leachate (i.e. $0.72 \mathrm{ml} / \mathrm{L}$ ) used in the study compared to that of Hyla sp. This increase in GSH level could also be ascribed to oxidative stress resulting from the exposure of Poecilia sp. to leachate.

\begin{tabular}{|c|c|c|c|c|c|c|}
\hline Conc(ml/L) & & GSH & SOD & CAT & MDA & GST \\
\hline \multicolumn{7}{|l|}{ Hyla $s p$} \\
\hline \multirow[t]{3}{*}{0.00} & Day 0 & $0.28 \pm 0.02^{\mathrm{a}}$ & $2.43 \pm 0.03^{\mathrm{a}}$ & $14.18 \pm 0.02^{\mathrm{a}}$ & $0.32 \pm 0.02^{\mathrm{a}}$ & $2.28 \pm 0.04^{\mathrm{a}}$ \\
\hline & Day 14 & $0.41 \pm 0.36^{\mathrm{a}}$ & $3.09 \pm 0.64^{\mathrm{a}}$ & $14.26 \pm 0.49^{\mathrm{a}}$ & $0.25 \pm 0.03^{\mathrm{a}}$ & $2.74 \pm 0.14^{\mathrm{a}}$ \\
\hline & Day 28 & $0.39 \pm 0.05^{\mathrm{a}}$ & $3.69 \pm 0.07^{\mathrm{a}}$ & $16.79 \pm 3.18^{\mathrm{a}}$ & $0.27 \pm 0.04^{\mathrm{a}}$ & $3.19 \pm 0.10^{\mathrm{a}}$ \\
\hline \multirow[t]{3}{*}{0.58} & Day 0 & $0.28 \pm 0.02^{\mathrm{a}}$ & $2.43 \pm 0.03^{\mathrm{a}}$ & $14.52 \pm 0.56^{\mathrm{a}}$ & $0.32 \pm 0.02^{\mathrm{a}}$ & $2.28 \pm 0.04^{\mathrm{a}}$ \\
\hline & Day 14 & $1.02 \pm 0.29^{\mathrm{a}}$ & $9.66 \pm 5.24^{b}$ & $88.21 \pm 7.92^{\mathrm{b}}$ & $0.65 \pm 0.24^{\mathrm{a}}$ & $13.35 \pm 8.86^{\mathrm{b}}$ \\
\hline & Day 28 & $3.25 \pm 0.23^{\mathrm{b}}$ & $9.73 \pm 1.48^{\mathrm{b}}$ & $110.46 \pm 6.57^{b}$ & $1.17 \pm 0.62^{\mathrm{b}}$ & $2.89 \pm 0.41^{\mathrm{a}}$ \\
\hline \multicolumn{7}{|l|}{ Poecilia sp } \\
\hline \multirow[t]{3}{*}{0.00} & Day 0 & $0.43 \pm 0.02^{\mathrm{a}}$ & $2.71 \pm 0.03^{\mathrm{a}}$ & $17.60 \pm 1.01^{\mathrm{a}}$ & $0.41 \pm 0.03^{\mathrm{a}}$ & $3.04 \pm 0.03^{\mathrm{a}}$ \\
\hline & Day 14 & $0.90 \pm 1.61^{\mathrm{a}}$ & $3.61 \pm 2.86^{\mathrm{a}}$ & $18.38 \pm 0.41^{\mathrm{a}}$ & $0.36 \pm 0.06^{\mathrm{a}}$ & $2.58 \pm 0.81^{\mathrm{a}}$ \\
\hline & Day 28 & $0.77 \pm 0.08^{\mathrm{a}}$ & $3.47 \pm 0.15^{\mathrm{a}}$ & $17.60 \pm 1.02^{\mathrm{a}}$ & $0.31 \pm 0.30^{\mathrm{a}}$ & $3.32 \pm 0.30^{\mathrm{a}}$ \\
\hline \multirow[t]{3}{*}{0.72} & Day 0 & $0.43 \pm 0.02^{\mathrm{a}}$ & $2.71 \pm 0.03^{\mathrm{a}}$ & $24.56 \pm 3.69^{\mathrm{a}}$ & $0.41 \pm 0.03^{\mathrm{a}}$ & $3.04 \pm 0.03^{\mathrm{a}}$ \\
\hline & Day 14 & $2.67 \pm 1.76^{\mathrm{b}}$ & $14.17 \pm 0.34^{\mathrm{b}}$ & $149.86 \pm 6.80^{\mathrm{a}}$ & $0.54 \pm 0.05^{\mathrm{a}}$ & $4.14 \pm 0.15^{\mathrm{a}}$ \\
\hline & Day 28 & $3.26 \pm 0.86^{\mathrm{b}}$ & $5.45 \pm 0.43^{\mathrm{a}}$ & $51.12 \pm 5.28^{\mathrm{b}}$ & $0.60 \pm 0.20^{\mathrm{a}}$ & $1.61 \pm 0.13^{\mathrm{a}}$ \\
\hline
\end{tabular}

The activity of GSH, SOD, and CAT showed significant increase in the sub-lethal exposure of Poecilia species to Olushosun leachate, while Hyla species had significant differences in mean values of all liver enzyme activities for exposed and control organisms. The results suggest induction of oxidative stress after exposure to leachate but also demonstrate guppy fish and tadpole capacity to up regulate their 
anti-oxidative defence against environmental pollutants.

Conclusion: The results obtained from the acute toxicity study show that the leachate is toxic and could be used in the risk assessment of leachate from landfills. This is important for monitoring the environmental safety of landfill sites in a bid to protect wildlife, public health and the environment at large. The present investigation indicated that the leachate is toxic to fish and tadpole and further substantiate earlier findings that antioxidant enzymes such as SOD, CAT, GSH and GST; and MDA in fish and tadpole could be effectively used as biomarkers of leachate toxicity.

Acknowledgements: The authors are grateful to Messrs Johnson Ojoniyi of Chemistry Department, and Sunday Adenekan of Biochemistry Department (both of UNILAG) for the physico-chemical and liver enzyme analyses respectively.

\section{REFERENCES}

Avci, A.; Kacmaz, M.; Durak, I (2005) Peroxidation in muscle and liver tissues from fish in a contaminated river due to petroleum refinery industry. Exotoxin. Environ. Safety. 6: 101-105.

Bagchi, A. (1994) Design, Construction and Monitoring of Landfills.2nd edition, John Wiley and Sons, New York. Pp. 78

Bhambulkar, A. (2011) 'Effects of Leachate Recirculation on a Landfill', Inter. J. Adv. Engineer. Sci. Technol. 11(2)286 - 291.

Cairns, J Jr (1956) Effects of increased temperatures on aquatic organisms. Industrial Wastes, 1, pp. 150-152.

Christensen, TH; Kjeldsen, P; Bjerg, PL; Jensen, DL; Christensen, BJ; Baum, A; Albrechtsen, HG (2001) Biogeochemistry of landfill leachate plumes. Appl. Geochem. 16: 659-718.

Clement, B; Persoone, G; Janssen, C; and A. Le DfiDelepierre, (1996) Estimation of the hazard of landfills through toxicity testing of leachates: Determination of leachate toxicity with a battery of acute tests. Chemosphere, 33: 2303-2320.

Fatima, RA; Ahmad, M (2005) Certain antioxidant enzymes of Allium cepa as biomarkers for the detection of toxic heavy metals in wastewater. Science of Total Environment, 346:256-273.
Horvat T; Vidaković-Cifrek Ž; Oreščanin V; Tkalec M; Pevalek-Kozlina B (2007) Toxicity assessment of heavy metal mixtures by Lemna minor L. Science of Total Environment, 384:229238.

Idowu ET; Amaeze NH; Adie PI; Otubanjo OA (2014) Heavy metal bioaccumulation and biomarkers of oxidative stress in the wild African tiger frog, Hoplobatrachus occipitalis. Afri. J. Environ. Sci. Technol. 8 (1): 6-15

Kerksick C; Willoughby D (2005). The Antioxidant Role of Glutathione and N-Acetyl-Cysteine Supplements and Exercise-Induced Oxidative Stress. J Int Soc Sports Nutr, 2(2):38-44

Khoury, R; El-Fadel, M; Sadek, S; Ayoub, G (2000). Temporal variation of leachate quality in seawater saturated fills. Advance Environmental Resource, $4: 313-323$.

Kjeldsen, P; Barlaz, MA; Rooker, AP; Baun, A; Ledin, A; Christensen, TH (2002) Present and long-term composition of MSW landfill leachate. Critical Rev. Environ. Sci. Technol. 32: 297-336.

Kruempelbeck, I; Ehrig, HJ (1999) Long-term behavior of municipal solid waste landfills in Germany. Proceedings of the 7th Symposium on Waste Management and Landfill, Sardinia, Italy, pp: 27-36.

Kulikowska, D; and Klimiuk, E (2008) 'The effect of landfill age on municipal leachate composition', Biores. Technol. 99(13): 5981-5985

López-López, E;Sedeño Diaz, J; Soto, C; Favari, L (2010) Responses of antioxidant enzymes, lipid peroxidation, and $\mathrm{Na}+\mathrm{K}+-\mathrm{ATPa} e$ in liver of the fish Goodea atripinnis exposed to Lake Yuriria water. Fish Physiology and Biochemistry, 37:511522.

McBean, A; Rovers, FA; Farquhar, GJ (1995) Solid waste landfill engineering and design[Online]. Available: http // www. hinkleycenter. com/publications/analysis_florida_msw_leachat e_97-3.pdf

Mor, S; Ravindra, K; Dahiya, RP; Chandra, A (2006) "Leachate characterization and assessment of groundwater pollution near municipal solid waste landfill site," Environ. Monitor. Assess. 4: 325334. 
Moturi, MC; Rawat, M; Subramanian, V (2004) "Distribution and fractionation of heavy metals in solid waste from selected cities in the industrial belt of Delhi, India," Environ. Monitor. Assess. 95: 183-199.

Pivato, A; Gaspari, L (2005) Acute toxicity test of leachates from traditional and sustainable landfills using luminescent bacteria. Waste Management, 26: 1148-1155.

Rand, GM (1995) Introduction to aquatic toxicology. Fundamentals of Aquatic Toxicology 2nd Edition, CRC Press: Florida, USA, pp 39.

Roos, D; Weenig, RS; Wyss SR; and Aebi, HE (1980) Protection of human neutrophils by endogenase catalase Studies with cell from catalase-deficient individuals. Journal of Clinical Investigation, $65(6): 1515-22$

Sen, CK; Packer L (2000) Thiol homeostasis and supplements in physical exercise. Am J Clin. Nutr, 72(2):653S-69S

Zhang, J; Fitsanakis, VA; Gu, G; Jing, D; Amarnath, V; Amontine, TJ (2003) Manganese ethylene-bisdithiocarbonate and selective dopaminergic neuro-degeneration in rat: a link through mitochondrial dysfunction. J. Neurochem.84: 336-346.

Zin, M; Shaylinda, N; Abdul Aziz, H; Adlan, M; Ariffin, A (2012) 'Characterization of leachate at Matang Landfill site, Perak, Malaysia', Acad. J. Sci. 1(2): 317-322. 